\title{
A NEW GLEICHENIOPSIS FROM THE UPPER CRETACEOUS OF WESTERN GREENLAND ${ }^{1}$
}

\author{
ERnest L. Miner
}

(Received for publication March 3I, 1933)

While examining the collection of fossil plants from Western Greenland, made by Mr. Carl O. Erlanson in 1928, portions of small fertile Gleicheniaceous fronds were observed. Some of them were merely impressions, but others had a coating of the carbonized plant tissue still adhering to the fine dark gray shale. The latter fronds proved to be of much interest.

The carbonized material was carefully removed from the shale, placed in dilute nitric acid and potassium chlorate for a short time, and then treated with ammonium hydroxide. Each sorus or other part of the fronds was macerated and examined separately. Compact groups or masses of spores were readily liberated from each sorus, but it was almost impossible to separate the individual spores. Several different methods were employed but with no satisfactory results. A few small fragments of the epidermis from the rachises were also recovered. All of this macerated plant material was mounted on slides by the euparal method (Miner, 1932).

Tutin (1932) proposed the genus Gleicheniopsis for certain species included in Gleichenites which differed markedly from Gleichenia in having numerous small sporangia per sorus and very few spores; but the differences between the two genera are not sufficient, as is shown by the intermediacy of Gleichenites Porsildii. Nevertheless, since the distinction has been made, it seems best to continue the use of both generic names until more evidence is at hand. The age of Gleichcniopsis is given as Lower Cretaceous, but the specimen described here appears to belong higher up in the Cretaceous series. Heer ( $1882, \mathrm{I} 883$ ) divided the Cretaceous rocks of Western Greenland into three series: Kome or Lower Cretaceous, Atane or Cenomanian, and Patoot, the uppermost Cretaceous. Seward (1925, 1927) made a critical study and revision of this flora and concluded that a more thorough examination of the sections is necessary, because with the available facts it is difficult to correlate accurately the Cretaceous series of Greenland with other regions and also because this flora represents more fully than any other the early stages in the transitional period from an older Jurassic-Wealden vegetation to the later type that continued into the Tertiary.

The shale bearing this material came from Patoot and Atâ on the Nugsuaks

1 Papers from the Department of Botany and Herbarium of the University of Michigan, No. 4I4. 
Peninsula. The Patoot specimen was collected at 255 meters above sea level and the Atâ specimen from strata about one mile southeast of the Atâ delta at an altitude between 150 and 165 meters. It is apparent that this material belongs to Heer's Atane or Patoot series, and it also comes within the limits of the Upper Cretaceous of Western Greenland as given by White and Schuchert ( 1898 ).

Gleicheniopsis Erlansonii, sp. nov. Pinnae alternate; pinnules opposite, obliquely-opposite or alternate, I-2 mm. wide, I.2-2.5 mm. long, ovate or obliquely-ovate, confluent at the base by a slender common lamina, apex rounded, directed forward; sinuses narrowly acute, .I-.25 mm. in width at about the middle of the pinnules; sori $3-6$ per pinnule, orbicular or nearly so, $500-900 \mu$ in diameter (average about $650 \mu$ ), crowded ; sporangia $16-40$ per sorus, orbicular or nearly so, 70-I $50 \mu$ in diameter (mean being about I05 $\mu$ ) ; spore masses clavate to pyriform, $65^{-1} 35 \mu$ in width, $155^{-225 \mu}$ in length, the average size being about $100 \times 185 \mu$; spores few (probably 32 ) per sporangium, deltoid, $40-50 \mu$ in diameter, with triradiate clefts extending twothirds or more of the distance to the periphery.-Patoot and Atâ on the Nugsuaks Peninsula, Western Greenland; Upper Cretaceous. Figures I-6.

The data for the shape and size of the sporangia were taken from the sori of the various pinnules, as seen without macerating, such as the ones shown in figures $I$ and 2. An annulus of a few unusually long indurated cells was observed on some of the sporangia but it was not well preserved, so that the exact number of cells could not be ascertained. Since the spores of each sporangium were always tightly compressed together into more or less the shape of the sporangium (see fig. 4 and 6), it was easy to determine the number of sporangia, per sorus, as each compact spore mass represents a single sporangium. It was almost impossible to separate the individual spores, so that the exact number in a sporangium could not be accurately determined, but it is estimated that the maximum number must be about $3^{2}$. The characteristic epidermal cells of the rachis are shown in figure 3. Both specimens agree very closely on all measurements except that the Patoot specimen has 4,5 , or 6 sori on a pinnule and I6-30 sporangia in a sorus, whereas the Atâ specimen has $3,4,5$, or 6 sori per pinnule and $16-40$ sporangia per sorus. The most common number of sori on a pinnule is 4 , and the others in the order of their occurrence are 5,6 , and 3 .

The following table gives in summarized form the main diagnostic characters for the species in this genus :

\begin{tabular}{lccccc}
\hline \hline Species & $\begin{array}{c}\text { No. of } \\
\text { sporangia } \\
\text { per sorus }\end{array}$ & $\begin{array}{c}\text { Diam. of } \\
\text { sporangia }\end{array}$ & $\begin{array}{c}\text { No. of } \\
\text { spores in } \\
\text { sporangium }\end{array}$ & $\begin{array}{c}\text { Size of } \\
\text { spores }\end{array}$ & $\begin{array}{c}\text { No. of } \\
\text { sori per } \\
\text { pinnule }\end{array}$ \\
\hline Glcicheniopsis & & & & & \\
Erlansonii & $16-40$ & $105 \mu$ & $32^{*}$ & $40-50 \mu$ & $3-6$ \\
G. fecunda & $20-40$ & $170 \mu$ & $18-26$ & $50-60 \mu$ & $5-7$ \\
G. Sczerardii & $12-20$ & $170 \mu$ & $32^{*}$ & $50 \mu^{*}$ & $2-4$ \\
\hline
\end{tabular}

* Estimate. 


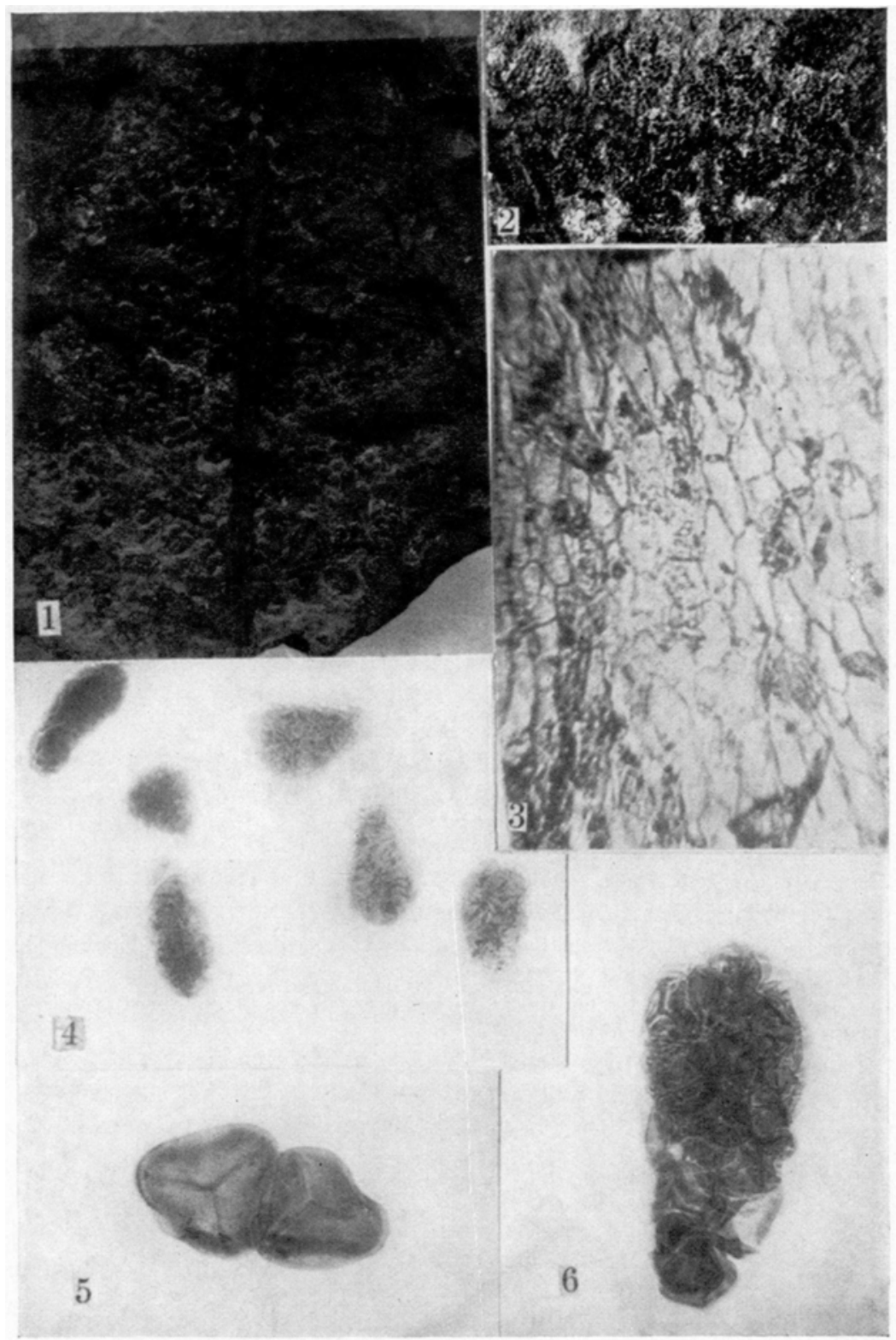

Fig. 1-6. Gleicheniopsis Erlansonii, sp. nov. Fig. I. A portion of a frond showing the attachment of the pinnae to the rachis and the pinnules with their sori. $\times 2.7$. Atâ, Greenland. Fig. 2. Part of a pinna enlarged showing several pinnules with sori. $X 5$. Patoot, Greenland. Fig. 3. Epidermal cells from the rachis. X 235. Atâ, Greenland. Fig. 4. A group of six spore masses showing the variation in size and shape. $X 106$. Patoot, Greenland. Fig. 5. Two characteristic spores separated from a spore mass, such as those shown in figures 4 and $6 . \times 340$. Patoot, Greenland. Fig. 6. A typical spore mass enlarged to show more clearly the compactness of the spores. $\chi^{\prime} 240$. Atà, Greenland. 
A comparison of the above species shows that they are all closely related and that $G$. Erlansonii is intermediate in the most obvious characteristic, namely, the number of sori per pinnule, between G. fecunda and G. Seriardii. It is entirely possible that all three represent the range of variation in a single species, but this can only be proved by the examination and study of much more material. In general, there is every evidence that in the description of fossil florulae too great conservatism is as common as too great radicalism in the recognition of species. Certainly the preservation of the plant remains of any modern habitat would give many more species than are recognized in the average florula. Moreover, habitats removed as far in space from one another as many fossil localities that are compared would not have anywhere near the high proportion of species in common that paleobotanists usually find. With no desire to encumber the literature with unnecessary names, it seems desirable from a scientific standpoint to emphasize distinctions rather than supposed identities.

\section{Department of Botany, UNIVERSITY OF MiChIGAN, Ann Arbor, Michigan}

\section{LITERATURE CITED}

HeEr, O. 1882. Die fossile Flora Grönlands. Flora Fossilis Arctica 6: I-112. I883. Die fossile Flora Grönlands. Flora Fossilis Arctica 7: 1-275.

MINer, E. L. 1932. Megaspores ascribed to Selaginellites, from the Upper Cretaceous coals of Western Greenland. Jour. Washington Acad. Sci. 22: 497-506.

Seward, A. C. 1925. Notes sur la Flore Crétacique du Groenland: Etude Critique. Livre Jubilaire, Soc. Géol. Belgique, p. 229-262.

- I927. The Cretaceous plant-bearing rocks of Western Greenland. Phil. Trans. Roy. Soc. London B, 215: 57-175.

Tutin, T. G. 1932. A Cretaceous Gleicheniaceous fern from Western Greenland. Annals Bot. 46: 503-508.

White, D., And C. Schuchert. I898. Cretaceous series of the west coast of Greenland. Geol. Soc. Amer. Bull. 9: 343-368. 